Ключевые слова: глобализация; международная торговля; европейский рынок; интеграция; асимметрия; экспорт; импорт; кластерный анализ; Европейский союз.

Virkovska Anastasiya,

Ph.D Fellow of the International Finance and Global Economy Department of S.I. Yurii, Ternopil National Economic University

\title{
FOREIGN TRADE INTEREST ASYMMETRY EVALUATION OF EUROPEAN COUNTRIES
}

The article reviews foreign trade interests of European countries. The globalization impact on the development of international trade in European countries is considered. The influence of asymmetry on foreign trade interests of European countries is investigated. The reasons for its occurrence are analyzed.

The globalization of the world economy and the deepening of the integration process (especially in Europe) extend asymmetries between countries both in macroeconomic indicators, positioning in the world, and on foreign trade interests. Each country has its own conditions of integration into the global trading space, according comparing the interests and capabilities of their implementation and taking into account their own capacities. The asymmetry of interests creates asymmetry of trade flows, which may manifest itself in the territorial (spatial) and temporal dimension.

Our analysis confirmed the existence of significant spatial and temporal asymmetries in the distribution of European countries by exports/imports trade flows of goods and services, it means that those countries in the implementation of foreign trade follows its own interests.

Key words: globalization; international trade; European market; integration; asymmetry; export; import; cluster analysis; European Union.

(C) Вірковська Анастасія

Надійшла до редакції 05.01.2015

УДК 339.09

\section{ГРОЗНИЙ ІГОР,}

доктор економічних наук, стариий науковий співробітник,

завідувач кафедри менеджменту Свропейського університету, м. Київ

МАЛЮКОВ ВОЛОДИМИР,

доктор фізико-математичних наук, доиент кафедри інформаційних систем та

математичних дисииплін Свропейського університету, м. Київ

\section{СПЕЦИФІКА КЛАСТЕРНИХ СТРАТЕГІЙ \\ В РОЗВИТКУ РЕГІОНІВ}

У роботі визначено характерні особливості та специфіку використання кластерних стратегій в розвитку регіонів. Зокрема простежено процес реалізації кластерної стратегії в рамках державного та регіонального управління. Акцентовано увагу на тому, що існує певна необхідність формування цілісної державної кластерної політики 3 відповідними видами забезпечення. Наведено переваги від упровадження кластерної стратегії в розвитку регіонів.

Ключові слова: кластер; стратегія; регіон; державне управління; механізм державної кластерної політики.

Постановка проблеми. Останні тенденції розвитку світової економіки визначаються зростаючою роллю промислових кластерів в умовах переходу економіки на інноваційний шлях розвитку. У зв'язку з цим задача фрормування єдиної інноваційної інфрраструктури, забезпечення ефективного використання національного нау- ково-технічного потенціалу, створення умов для прискореного розвитку регіонів та їх найбільш процвітаючих, конкурентоспроможних сегментів набуває першочергового значення.

У контексті вищезазначених тенденцій інноваційна активність характеризується високим рівнем геогра- 
фічної концентрації, що принципово змінює статус окремих національних регіонів і великих міст на міжнародному ринку високотехнологічної продукції, перетворюючи їх на вузлові точки глобальної інноваційної мережі. Саме в даному контексті стратегічного значення набуває формування регіональної інноваційної системи як необхідної передумови підвищення інноваційної спроможності та, відповідно, міжнародної конкурентоспроможності регіону [1]. Адже важливими для розвитку й утримання переваги над конкурентами $€$ не лише інновації та освіта, а й взаємозв'язок між підприємствами, який веде до створення мережевих структур - кластерів.

Аналіз останніх досліджень і публікацій. Сучасний світовий досвід формування кластерної політики знайшов своє відображення в працях зарубіжних авторів: А. Маршалла, М. Портера, Т. Андерссона, К. Кетельса, Л. Янга, Т. Харріса та ін. Серед українських варто виділити праці М. Войнаренка, В. Гейця, С. Соколенка, В. Федоренка та ін. У той же час проблема вдосконалення процесів управління фрормуванням регіональних кластерів з позиції підвищення конкурентоспроможності утвореної структури видається недостатньо вивченою і опрацьованою, що передбачає проведення відповідних науково-теоретичних досліджень.

Метою роботи $є$ визначення специфіки кластерних стратегій в розвитку регіонів.

Виклад основного матеріалу. Про переваги формування стійкої мережі взаємодій між економічними агентами для забезпечення їх конкурентоспроможності науковці заговорили досить давно. Одним із найбільш ранніх досліджень у цьому напрямі можна вважати книгу Альфреда Маршалла "Принципи політичної економії" [5], у якій був спеціально виділений розділ, присвячений феноменам особливих промислових регіонів (industrial agglomerations) Великобританії.

Беручи за основу класичні ознаки кластера за М. Портером [6], ми можемо говорити про кластер як групу географічно локалізованих взаємозалежних компаній, постачальників обладнання, комплектуючих, спеціалізованих послуг, інфраструктури, науково-дослідних інститутів, вузів та інших організацій, що взаємодоповнюють одна одну й підсилюють конкурентні переваги окремих компаній і кластера в цілому. Іншими словами, кластер - група організацій (компаній, підприємств, об'єктів інфраструктури, науково-дослідних інститутів, вузів тощо), пов'язаних відносинами територіальної близькості й функціональної залежності в сорері виробництва продукції, її реалізації й споживання ресурсів.

У якості основних характеристик кластерів можна визначити наступне:

- географічна концентрація (близько розташовані фірми розпочинають співпрацю завдяки можливості заощаджувати на швидкій економічній взаємодії, обмінюватися соціальним капіталом і проводити спільне навчання персоналу);

- загальне соціально-економічне середовище;

- спеціалізація (кластери концентруються навколо певної сфери діяльності, до якої всі учасники мають відношення);

- множинність економічних агентів (кластери і їх діяльність охоплюють не тільки фрірми, що входять у кластер, а й громадські організації, академії, фрінансових посередників, інститути, що сприяють кооперації, тощо);
- множинність прямих та зворотних зв'язків між економічними агентами (кластери являють собою складну систему, елементи якої поєднуються прямими й зворотними зв'язками: матеріальними, інформаційними та ффінансовими потоками);

- конкуренція та співробітництво (як основні види взаємодій між фрірмами-членами кластера, які притаманні їм у однаковій мірі);

- досягнення необхідної критичної маси в розмірі кластера для отримання ефектів внутрішньої динаміки розвитку;

- життєвий цикл кластерів (вони розраховані на довгострокову перспективу);

- залучення в інноваційний процес (фірми й підприємства, що входять до складу кластера, зазвичай включені в процеси технологічних, продуктових, ринкових та/ або організаційних інновацій);

- кластерна форма організації призводить до створення особливої форми інновації - "сукупного інноваційного продукту" [7].

Підхід до розробки кластерної стратегії передбачає розробку та впровадження наступних заходів:

1. Ураховувати рівень спроможності - формування кластерної стратегії має базуватись на існуючій інституційній спроможності, рівні компетенцій та наявних ресурсах.

2. Націленість на впровадження - розробка стратегії має супроводжуватись пілотуванням практичного інструментарію політики - впровадження регіональних програм, включення пріоритетів та підходів кластерної стратегії до механізмів підтримки регіонального розвитку та галузевих програм.

3. Бути проактивною, тобто враховувати розробки щодо нових методів та підходів до формування кластерної політики, а не ретроактивною (копіювати те, що вже зроблено і впроваджено деінде).

4. Використовувати наявний інструментарій. В умовах України це означає, що кластерна стратегія має використовувати інструментарій програм регіонального розвитку з Фонду підтримки регіонального розвитку, угоди між КМУ та областями, програми галузевого розвитку та інші програми.

5. Узгоджуватись з іншими політиками - кластерна стратегія залежить і пов'язана з політикою регіонального розвитку, промисловою політикою та політикою розвитку інновацій.

Погоджуємося з думкою автора роботи [4], що виконання даного підходу обумовлює необхідність формування цілісної державної кластерної політики з відповідними видами забезпечення, які в сукупності представляють наступний механізм (рис. 1).

Як свідчить досвід розвинених країн, конкретні кластерні стратегії обумовлюються національними особливостями економік та основними характеристиками кластерів, комбінацією яких вони визначаються. До них належать: географічна (побудова просторових кластерів економічної активності), горизонтальна (входження декількох галузей/секторів у більш великий кластер), вертикальна (присутність у кластерах суміжних етапів виробничого процесу), латеральна (об'єднання у кластер різних секторів, що здатне забезпечити економію внаслідок ефекту масштабу), технологічна (сукупність галузей, які використовують одні й ті ж технології), фрокусна (кластер фрірм, які зосереджені навколо одного центру - підприємства, НДІ, чи навчального закладу), якісна (характер співробітництва фрірм і спосіб, у який воно здійснюється) [2]. 


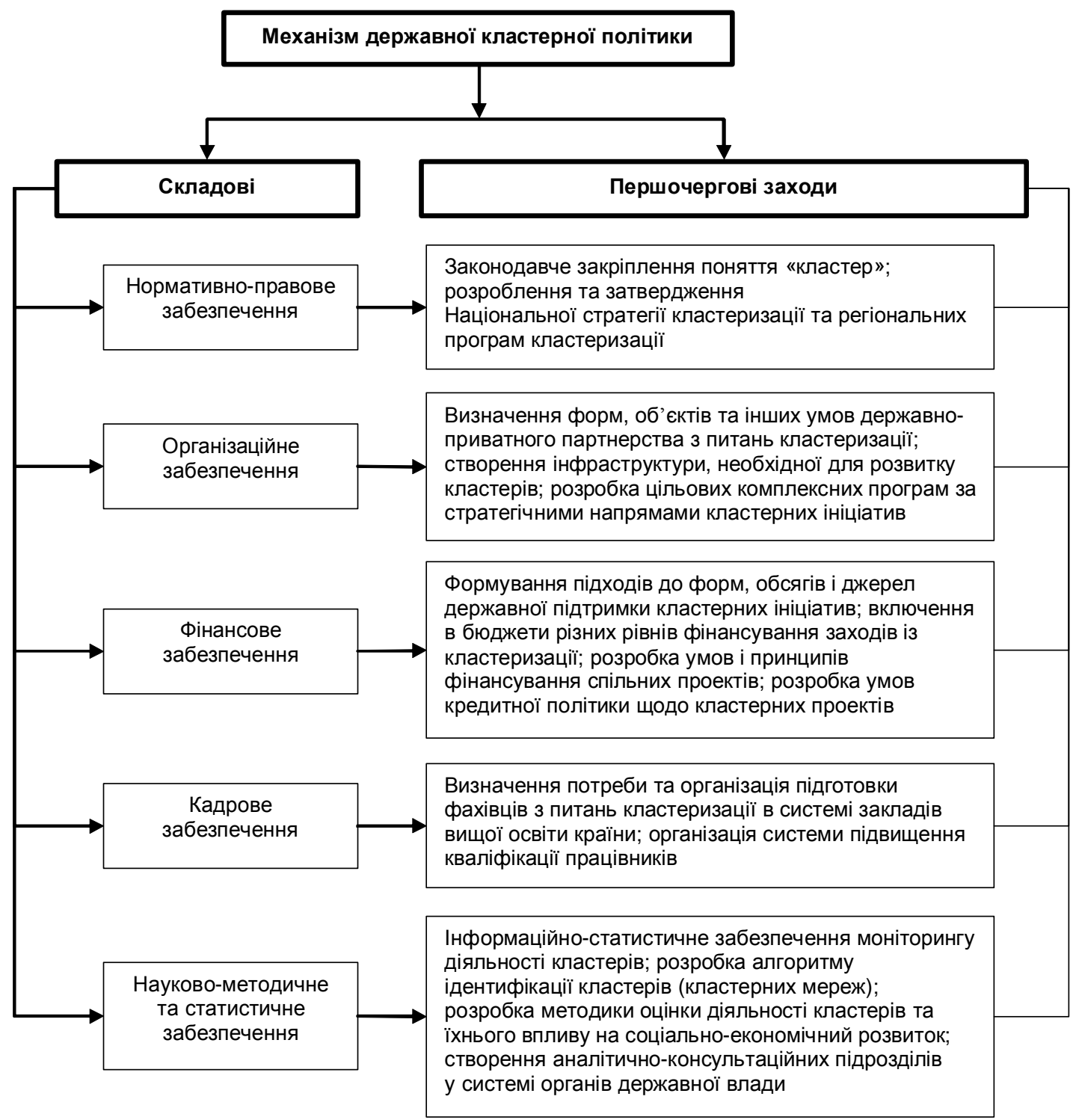

Рис. 1. Складові механізму державної кластерної політики [4].

На жаль слід визнати, в Україні донині не створено належного ані стратегічного, ані правового підґрунтя для практичної реалізації кластерного підходу, що не дозволяє повноцінно використовувати закладений у кластерній формі сучасної організації економіки інноваційний потенціал. Так, з 2008 р. залишається несхваленою Концепція створення кластерів в Україні, якою, зокрема, окреслено загальні засади створення та розвитку кластерів, у тому числі інноваційних, заохочення підприємств у ділові мережі, заходи щодо сприяння створенню кластерів у наукоємних і високотехнологічних галузях, формування регіональних кластерів та інституцій [3].

Однак важливо розуміти, що кластери можуть принести результати тільки тоді, коли вони вписані в більш широкий контекст стратегій економічного розвитку. Відтак, основними напрямками сприяння розвитку кластерів $\epsilon$, в першу чергу, сприяння інституційному й інфраструктурному розвитку економіки регіону, що забезпечить зміцнення господарської й інформаційної взаємодії між учасниками кластера. Учасники кластера поєднують свої ресурси і ресурси фінансових інститутів для створення нової продукції, досягнення більшої економічної ефективності й одержання доступу до нових технологій і нових ринків. Сприяння організаційному розвитку кластерів передбачає надання підтримки з боку органів влади в реалізації учасниками кластера наступних заходів:

1. Створення спеціалізованої установи з розвитку кластера, що забезпечить координацію діяльності його учасників.

2. Проведення аналізу структури кластера, ланцюжка виробництва учасниками кластеру доданої вартості, визначення бар'єрів і можливостей для розвитку кластера.

3. Розробка стратегії розвитку кластера та плану заходів щодо ії реалізації, що включає розробку набору кластерних проектів і заходів, спрямованих на фрормування сприятливих умов розвитку кластера.

4. Встановлення ефективної інформаційної взаємодії між учасниками кластера.

5. Реалізація заходів для стимулювання співробітництва між учасниками кластера (організація конференцій, семінарів, робочих груп, створення спеціалізованих інтернет-ресурсів тощо) [1]. 
Як справедливо зауважено у [8], переваги застосування кластерної політики для органів державної і регіональної влади полягає в тому, що вона дозволяє комплексно, системним чином розглядати ситуацію в групі взаємопов'язаних підприємств, які належать до різних галузей. Для держави це, насамперед, найбільш сучасний, зручний інструмент в економічній і податковій політиці.

\section{Висновки}

Таким чином, визначено, що використання кластерних стратегій в розвитку регіонів повною мірою узгоджується 3 тим, що однією $з$ цілей кластера $є$ або створення, або освоєння нових технологій, продуктів, послуг. Держава має забезпечити функціонування відповідного механізму управління кластерами (тобто проводити адекватну державну кластерну політику), що включає: розробку та реалізацію національної стратегії кластеризації; розвиток державно-приватного партнерства в питаннях кластеризації; створення інфраструктури, необхідної для розвитку кластерів; фрінансування (часткове або повне) заходів із кластеризації; розробку умов кредитної політики щодо кластерних проектів, організацію підготовки фахівців з кластеризації в системі вищої освіти країни; моніторинг діяльності кластерів тощо.

Переваги кластера для його учасників носять об'єктивний характер, тобто не залежать конкретно ні від одного з них, тому потенційно вони більш стійкі, ніж об'єднання іншого типу.

\section{ЛГТЕРАТУРА}

1. Кластеризация предприятий: состояние и перспективы // Наука. Инновации. Образование / [под. ред. Е. В. Семёнова]. - 2008. - Вып.7. - 312 с.

2. Цихан Т. В. Кластерная теория экономического развития [Электронный ресурс] / Т. В. Цихан // Теория и практика управления. - 2003. - № 5. - Режим доступа : http:// subcontract.ru/Docum/DocumShow_DocumID_168.html.

3. Концепція створення кластерів в Україні (проект) / Департамент інвестиційної та інноваційної діяльності [Електронный ресурс]. - Режим доступу : http://biznes.od.ua/ index.php?option=com_content\&task=view\&id=499\&ltemid=33.

4. Тищенко О. П. Державна кластерна політика в контексті формування інноваційної моделі розвитку національної економіки [Електронний ресурс] / О. П. Тищенко, С. А. Заніздра // БізнесІнформ. - 2014. - № 8. - С. 34-39. - Режим доступу : http://www.business-inform.net/pdf/2014/8_0/34_39.pdf.

5. Маршалл А. Принципы политической экономии / А. Маршалл. - М. : Директмедиа Паблишинг, 2008. - 332 с.

6. Портер М. Международная конкуренция / М. Портер. М. : Международные отношения, 1993. - 896 с.

7. Заремський Б. В. Кластерна стратегія інноваційного розвитку регіонів в контексті глобальної економіки [Електронний ресурс] / Б. В. Заремський // Инвестиционные приоритеты эпохи глобализации: влияние на национальную экономику и отдельный бизнес : III Международная научно-практическая конференция (7-8 октября 2010 года). - Режим доступу : http://www.confcontact.com/20101008/2 zarem.htm.

8. Ульянченко Ю. О. Методологічні засади формування кластерної політики в умовах глобалізації [Електронний ресурс] / Ю. О. Ульянченко // Державне будівництво. - 2010. № 2. - Режим доступу : http://www.kbuapa.kharkov.ua/e-book/ $\mathrm{db} / 2010-2 /$ doc/1/06.pdf.

Грозный Игорь,

доктор экономических наук, старший научный сотрудник,

заведующий кафедрой менеджмента Европейского университета, г. Киев

Малюков Владимир,

доктор физико-математических наук, доцент кафедры информационных систем и математических дисииплин Европейского университета, г. Киев

\section{СПЕЦИФИКА КЛАСТЕРНЫХ СТРАТЕГИЙ В РАЗВИТИИ РЕГИОНОВ}

В работе определены характерные особенности и специфика использования кластерных стратегий в развитии регионов. В частности прослеживается процесс реализации кластерной стратегии в рамках государственного и регионального управления. Акцентировано внимание на том, что существует определенная необходимость формирования целостной государственной кластерной политики с соответствующими видам и обеспечения. Обозначены преимущества от внедрения кластерной стратегии в развитии регионов.

Ключевые слова: кластер; стратегия; регион; государственное управление; механизм государственной кластерной политики.

Hroznyi Ihor,

Doctor of Economics, Senior Research Fellow, Head of Management European University, Kyiv

Malyukov Volodymyr,

Doctor of physical and mathematical sciences, associate professor of information systems and mathematical sciences European University, Kyiv

\section{CLUSTER SPECIFIC STRATEGIES IN DEVELOPMENT OF REGIONS}

The paper identified the characteristics and specific use of cluster strategies in regional development. Systematized measures that should be present in the cluster development strategy. The attention to the fact that there is a need to form a coherent cluster of public policy with appropriate forms of protection. The mechanism of state cluster policy should include: development and implementation of national strategies and relevant regional clustering programs; development of public-private partnership of matters to clustering; creating the infrastructure necessary for the development of clusters; approaches to formation of forms, volumes and sources of government support cluster initiatives; financing (partial or complete) measures clustering; development of the loan policy for 
cluster projects, organization of training in clustering in higher education in the country; monitoring of clusters and other components.

It is shown that the benefits of cluster policy for the state and regional authorities is that it allows a comprehensive, systematic way to consider the situation of a group of related enterprises in different sectors. For the state is, above all, the most modern and convenient tool in the economic and tax policy.

Keywords: cluster; strategy; region; state management; mechanism of state cluster policy.

\section{REFERENCES}

1. Clustering of enterprises: state and prospects (2008), Almanac «Science. Innovation. Education»; Issue 7, 312 p. (rus).

2. Tsykhan T. (2003), Cluster Theory of Economic Development, The theory and practice of management, № 5, available at: http:/ /subcontract.ru/Docum/DocumShow_DocumID_168.html (rus).

3. The concept of clusters in Ukraine (draft) (2008), Department of investment and innovation, available at: http://biznes.od.ua/ index.php?option=com_content\&task=view\&id=499\&ltemid=33 (ukr).

4. Tyshchenko A. P., Zanizdra S. A. (2014), State Cluster Policy in the Context of the Formation an Innovative Model of Development of the National Economy, Business-Inform, № 8, p. 34-39, available at: http://www.business-inform.net/pdf/2014/8_0/34_39.pdf. (ukr).

5. Marshall A. (2008), Principles of Political Economy, Directmedia Publishing, Moscow, 332 p. (rus).

6. Porter M. (1993), International competition, International Relations, Moscow, 896 p. (rus).

7. Zaremskyi B. V. (2010), The cluster strategy of innovative development of regions in the context of the global economy, in: III International scientific-practical conference «Investment priorities for the globalization era: the impact on the national economy and private business», available at: http://www.confcontact.com/20101008/2_zarem.htm (ukr).

8. Ulianchenko Y. O. (2010), Methodological bases of formation of cluster policy in the context of globalization, Derzhavne budivnytstvo [State building], № 2, available at: http: //www.kbuapa.kharkov.ua/e-book/db/2010-2/doc/1/06.pdf (ukr).

(С) Грозний Ігор, Малюков Володимир

Надійшла до редакції 13.01.2015

УДК 338.26

ЗАЛОЗНОВА ЮЛІЯ, доктор економічних наук, завідувач сектора сочіально-економічних проблем промислового розвитку Інституту економіки промисловості НАН Украӥни

\section{СОЦІОЕКОНОМІЧНІ ОСОБЛИВОСТІ МОДЕРНІЗАЦІї СУСПІЛЬНИХ ВІДНОСИН НА ЗАСАДАХ СОЦІАЛЬНОї ВІДПОВІДАЛЬНОСТІ}

У статті розкрито особливості формування системи соціальної відповідальності на засадах соціоекономіки. Оцінено ступінь розробленості цієї проблематики. Визначено потреби модернізації державного управління на підставі результатів експертного опитування науковців та освітян. Обґрунтовано перешкоди на шляху становлення соціальної відповідальності людини, суспільства, держави, бізнесу. Визначено мотиви ініціації та стимулювання становлення й розвитку соціальної відповідальності в системі суспільних відносин на засадах соціоекономіки.

Ключові слова: соціоекономіка; соціальна відповідальність; модернізація; суспільні відносини; цінності; духовність; довіра; людина; бізнес; держава.

Постановка проблеми. Соціальна відповідальність украй повільно стає нормою поведінки людини, суспільства, бізнесу, держави в Україні. Від цього потерпає і соціальна, і економічна, і духовно-культурна сфери. Незважаючи на взяті міжнародні зобов'язання країни, яка визнала міжнародний стандарт "Керівництво із соціальної відповідальності ISO-26000", підписала Глобальний договір, значних успіхів у цьому напрямку не простежується. Власне вітчизняна правова база соціальної відповідальності розвинута слабо. А негативні наслідки такого стану речей стають більш вагомими та загрозливими. Тому постає питання зміни традиційних підходів запровадження соціальної відповідальності на нетрадиційні. Перш за все - це використання соціоекономічних підходів до усвідомлення, узагальнення та визначення шляхів використання інноваційних підстав для визнання та застосування соціальної відповідальності [1]. 